\title{
Psychometric characteristic of positive affect scale within the academic setting
}

\author{
${ }^{* 1}$ Kartika Nur Fathiyah; ${ }^{2}$ Asmadi Alsa; ${ }^{3}$ Diana Setiyawati \\ ${ }^{1}$ Faculty of Education, Universitas Negeri Yogyakarta \\ Jl. Colombo No. 1, Karangmalang, Depok, Sleman, Yogyakarta 55281, Indonesia \\ ${ }^{2,3}$ Faculty of Psychology, Universitas Gadjah Mada \\ Jl. Sosio Humaniora Bulaksumur, Karangmalang, Sepok, Sleman, Yogyakarta 55281, Indonesia \\ ${ }^{*}$ Corresponding Author. E-mail: kartika.fip_uny@yahoo.co.id
}

Submitted: 9 July 2019 | Revised: 5 September 2019 | Accepted: 12 September 2019

\begin{abstract}
This analysis study is one of several stages that must be passed before testing the structural model. This study is initiated due to the limited information related to the measurement of the Positive Affect Scale within the academic settings. The research method used in this study was a quantitative method. It was done in among 724 students of state junior high schools in Sleman, Yogyakarta. The instrument development consisted of guideline arrangement, language feasibility testing, content validation through expert judgments, trials to measure the item discrimination index, item selection based on the item discrimination results, items representation for each indicator, and the construct validity test for the selected items. The testing of the measurement model used the data analysis techniques of Structural Equation Models (SEM) with the assistance of the AMOS program version of 21. The results of the study show that the validity analysis of the Positive Affect Scale within the academic setting was able to produce items that can reveal constructs or latent concepts appropriately.
\end{abstract}

Keywords: positive affect scale, validity analysis, academic setting

Permalink/DOI: https://doi.org/10.21831/reid.v5i2.25992

\section{Introduction}

Affect plays a significant role in people's life (Nath \& Pradhan, 2012) consisting of positive and negative form. Affect usually refers to one's emotion that is recognized and described as pleasantness or unpleasantness (Watson, Clark, \& Tellegen, 1988). The negative form provides short-term benefits to facilitate the tendency of specific behaviors in the form of responses, while the positive affect brings long-term benefits (Fredrickson, 1998). The negative form includes tension, hopelessness, fear, and irritation, while the positive form covers spirit, strength, activeness, desire, and stamina (Yik, Russell, \& Steiger, 2011).

The positive affect reflects the expansion of high energy, vigor and alert that make an individuals excited, full of concentration, and pleasant feeling. On the other hand, the low positive affect creates sadness and fatigue (Watson et al., 1988). The positive affect means a person's tendency to have a variety of positive emotional experiences (Watson et al., 1988). Related to the trait (the tendency of an individual state to be relatively stable), the positive affect is associated with the more frequent and intense episodes experienced by individuals. Based on the state (the person's condition at a certain time), the positive affect is a beneficial emotional experienced at a particular time (Watson \& Tellegen, 1985).

The positive affect is a key component of assessment and effective coping towards stressful situations (Folkman, 2008), and an antidote to negative emotions that can reduce its harmful influence (Fredrickson, Tugade, 
Waugh, \& Larkin, 2003). It develops a mental readiness to grow and step out from unpleasant situations and escalates sources of psychological coping to face stressors (Fredrickson, Mancuso, Branigan, \& Tugade, 2000). This affect can also maintain physical and psychological health (Danner, Snowdon, \& Friesen, 2001), and build personal resources and wellbeing (Fredrickson \& Joiner, 2002).

Based on Neurobiological perspective, the positive affect occurs due to the release of large amounts of dopamine from temporary phasic to synaptic clefts. The dopamine is then multiplied through the midbrain of the dopaminergic system to the striatum, limbic area, and prefrontal cortex (Ashby, Isen, \& Turken, 1999). Several studies have found that positive effects improve performance based on front striatal dopaminergic interactions among healthy individuals (Demanet, Liefooghe, \& Verbruggen, 2011).

Studies in various settings have revealed the role of positive affect in improving individual outcomes (Samios, Abel, \& Rodzik, 2013; Lyubomirsky, King, \& Diener, 2005); Steptoe, Dockray, \& Wardle, 2009). In the academic field, the role of positive affect is considered as very meaningful (Schutz \& Lanehart, 2002; Goetz, Pekrun, Hall, \& Haag, 2006) because it affects teaching and learning (Schutz \& Lanehart, 2002), student's subjective well-being, process quality, learning achievement, teacher interaction with students, and learning process effectiveness (Goetz et al., 2006). Those roles indicate the importance of positive affect within the academic setting.

In fact, the availability of information on the positive affect in the academic setting is very limited (Linnenbrink-Garcia \& Pekrun, 2011) and tends to have little attention from researchers (Pekrun et al., 2010). Therefore, Linnenbrink (2006) and also Seligman, Ernst, Gillham, Reivich, and Linkins (2009) suggest that psychological studies within an academic context should be gained more, especially development of positive affect scale within academic setting, as instrument to measure and support the optimal school functioning.

This research aims at elevating the study on the role of positive affect within the academic setting by developing a proper in- strument. Many researches in various settings on the positive affect including those in the academic setting have been using the concept of Watson et al. (1988) considered less specific. As a result, the positive affect cannot be optimally explored based on its context.

In the academic settings, Pekrun (1992) identifies the positive affect or emotions from motivation, learning process, and student performance. He classifies positive affect in the academic setting into positive affect related to assignments and social. Regarding the task, the positive affect comes from (a) the process, as a pleasure when undergoing the academic process; (b) anticipatory joy, as a positive affect that arises before the academic process takes place with happy feeling imagining the results to be achieved and the expectation towards the academic activities; and (c) prospective, a positive affect after the academic process takes place shown by a joy feeling because of the achieved success (joy of success), and satisfaction, pride and relief after undergoing the academic process. Meanwhile, the social concerns on the positive affect that appears because of social interactions during the academic process. The indicators are gratitude, empathy, admiration, and sympathy or love.

The specific measurement model discusses the relation between latent variables (constructs) and measurement indicators, by conducting an instrument construct validity analysis to reveal how well the measurement indicators measure the latent (construct) concept. Construct validity test includes exploratory and confirmatory factor analysis.

Exploratory factor analysis (EFA) is for situations where the relation between observed and latent variables is not known so it requires exploration to determine how and how closely the observed variables relate to the underlying (latent) factors. Conversely, in the confirmatory factor analysis (CFA), the factor structure is assumed to be known (Dachlan, 2014). Because the indicators of this research have been theorized by Pekrun (1992), the analysis was done using CFA. Thus, this paper aims to confirm whether the scale of positive affect within academic setting built already matched between the data obtained with the underlying theory. 


\section{Method}

The research method used in this study was quantitative method. This study was conducted among the junior high school students in Sleman, Yogyakarta. The subject involved in this study were 724 students, including 359 students in the field trial stage and 365 for the empirical data collection. The data collection at each stage was done to different subjects. The analysis in the field trial used discrimination test, while the validation analysis in this study was the analysis of the empirical data collection in addition to the model testing.

The instrument development consisted of guideline arrangement, language feasibility test, content validation through calculated by Aiken's V formula, discrimination index, item selection based on the item discrimination results, items representation for each indicator, the construct validity test in the selected items and validity and reliability test. The Aiken's formula is described as follows (Aiken, 1985).

Notes:

$$
\mathrm{V}=\sum \mathrm{s} /[\mathrm{n}(\mathrm{c}-1)]
$$

$1=$ the lowest of validity assessment score (equal to 1)

$\mathrm{c}=$ the highest of validity assessment score (equal to 4 )

$\mathrm{r}=$ the score from the assessor

$\mathrm{n}=$ number of assessors $=\mathrm{r}-1$

The testing of positive affect scale in the academic setting employed Structural Equation Models (SEM) with the assistance of AMOS program version 21. To determine the Goodness of Fit Index (GFI) according to Dachlan (2014), it used several criteria: ChiSquare and p-values, CMIN/DF, GFI, AGFI
(Adjusted Goodness of Fit Index), CFI (Comparative Fit Index), TLI (Tucker-Lewis Index), and RMSEA (Root Mean Square Error of Approximation).

\section{Findings and Discussion}

\section{Findings}

The initial step of the study in carrying out the validity test of the positive affect scale is to make the guidelines for the instruments. This guideline was arranged referring Pekrun's (1992) theory regarding the general taxonomy of positive emotions relevant to motivation, learning process, and student performance. The scale contains two aspects: (1) task and (2) social aspects. The positive affect scale comprises statements related to school activties. The students were asked to respond each statement based on their experience, feeling, and thought. This scale contains statements that support (favorable) and those that do not support (unfavorable). There were two models of answer choices to respond to the statements. The first model includes the frequency/intensity of 'never', 'rarely', 'sometimes', 'often', and 'always' with the score range from 1 (never) to 5 (always) respectively, while the second model focuses on its appropriateness containing 'very inappropriate', 'inappropriate', 'sometimes', 'appropriate', and 'very appropriate' with the score range from 1 (very inappropriate) to 5 (very appropriate) respectively. The number on the positive affect scale of the trial stage were 30 items. The details of the dimensions, indicators, and number of items is shown in Table 1, while the scale is presented in Figure 1.

Table 1. The guideline of positive affect scale

\begin{tabular}{lllc}
\hline Aspects & \multicolumn{1}{c}{ Indicator } & \multicolumn{1}{c}{ Sub-Indicators } & Number of Test Item \\
\hline Tasks & Process & Joy & 3 \\
& & Anticipatory joy & 3 \\
& Prospective & Hope & 3 \\
& Retrospective & Joy about success & 3 \\
& & Satisfaction & 3 \\
& & Pride & 3 \\
Social & Gratitude & 3 \\
& & Empathy & 3 \\
& & Admire & 3 \\
& & Love & 3 \\
& & Total number of test items & 30 \\
\hline
\end{tabular}




\section{Instruction}

\section{POSITIVE AFFECT SCALE}

The following statements are about your experiences, your feeling and your thought related to the school activities. Please, give response on each statement with cross mark $(\mathrm{X})$ based on your condition with the following possible answers.

\begin{tabular}{|c|c|l|}
\hline Never & $\mathrm{Nv}$ & Never experiencing \\
\hline Rarely & $\mathrm{Rr}$ & Rarely experiencing \\
\hline Sometimes & $\mathrm{Sm}$ & Sometimes experiencing \\
\hline Often & $\mathrm{Oft}$ & Often experiencing \\
\hline Always & $\mathrm{Alw}$ & Always experiencing \\
\hline
\end{tabular}

A. The frequency of experiencing the following items in schools

\begin{tabular}{|c|l|c|c|c|c|l|}
\hline 1. & You are enthusiastic in completing the school assignments & $\mathrm{Nv}$ & $\mathrm{Rr}$ & $\mathrm{Sm}$ & $\mathrm{Oft}$ & $\mathrm{Alw}$ \\
\hline 2. & Your feel comfortable at the school & $\mathrm{Nv}$ & $\mathrm{Rr}$ & $\mathrm{Sm}$ & $\mathrm{Oft}$ & $\mathrm{Alw}$ \\
\hline 3. & $\begin{array}{l}\text { You feel happy when imagining the school assignments has been } \\
\text { finished }\end{array}$ & $\mathrm{Nv}$ & $\mathrm{Rr}$ & $\mathrm{Sm}$ & $\mathrm{Oft}$ & $\mathrm{Alw}$ \\
\hline 4. & You feel happy when imagining the school graduation & $\mathrm{Nv}$ & $\mathrm{Rr}$ & $\mathrm{Sm}$ & $\mathrm{Oft}$ & $\mathrm{Alw}$ \\
\hline 5. & You miss your school friends & $\mathrm{Nv}$ & $\mathrm{Rr}$ & $\mathrm{Sm}$ & $\mathrm{Oft}$ & $\mathrm{Alw}$ \\
\hline 6. & You want to do the best for your school & $\mathrm{Nv}$ & $\mathrm{Rr}$ & $\mathrm{Sm}$ & $\mathrm{Oft}$ & $\mathrm{Alw}$ \\
\hline 7. & You care to your friends who experience learning difficulty & $\mathrm{Nv}$ & $\mathrm{Rr}$ & $\mathrm{Sm}$ & $\mathrm{Oft}$ & $\mathrm{Alw}$ \\
\hline 8. & You feel happy when your friend attain academic success & $\mathrm{Nv}$ & $\mathrm{Rr}$ & $\mathrm{Sm}$ & $\mathrm{Oft}$ & $\mathrm{Alw}$ \\
\hline
\end{tabular}

B. The frequency of expectation towards following items in schools :

\begin{tabular}{|l|l|l|l|l|l|l|}
\hline 1. & You expect to complete your assignments as best as you can & $\mathrm{Nv}$ & $\mathrm{Rr}$ & $\mathrm{Sm}$ & $\mathrm{Oft}$ & Alw \\
\hline 2. & You expect to graduate with the highest score & $\mathrm{Nv}$ & $\mathrm{Rr}$ & $\mathrm{Sm}$ & $\mathrm{Oft}$ & Alw \\
\hline
\end{tabular}

C. The frequency of happiness due to the following items.

\begin{tabular}{|c|l|l|l|l|l|l|}
\hline 1. & You succeed to finish the difficult test/ exercise item & $\mathrm{Nv}$ & $\mathrm{Rr}$ & $\mathrm{Sm}$ & $\mathrm{Oft}$ & Alw \\
\hline 2. & You gain better school results that the previous semester & $\mathrm{Nv}$ & $\mathrm{Rr}$ & $\mathrm{Sm}$ & $\mathrm{Oft}$ & $\mathrm{Alw}$ \\
\hline
\end{tabular}

D. The frequency of satisfaction due to the following items.

\begin{tabular}{|l|l|l|l|l|l|l|}
\hline 1. & The teachers' teaching strategies & $\mathrm{Nv}$ & $\mathrm{Rr}$ & $\mathrm{Sm}$ & $\mathrm{Oft}$ & Alw \\
\hline 2. & The test score & $\mathrm{Nv}$ & $\mathrm{Rr}$ & $\mathrm{Sm}$ & $\mathrm{Oft}$ & $\mathrm{Alw}$ \\
\hline
\end{tabular}

E. The frequency of proud feeling due to the following items.

\begin{tabular}{|l|l|l|l|l|l|l|}
\hline 1. & Your academic achievement & $\mathrm{Nv}$ & $\mathrm{Rr}$ & $\mathrm{Sm}$ & Oft & Alw \\
\hline 2. & Your learning progress & $\mathrm{Nv}$ & $\mathrm{Rr}$ & $\mathrm{Sm}$ & Oft & Alw \\
\hline
\end{tabular}

F. The frequency of relief feeling due to the following items.

\begin{tabular}{|l|l|l|l|l|l|l|}
\hline 1. & You gain the scores above the Minimum Completeness Criteria & $\mathrm{Nv}$ & $\mathrm{Rr}$ & $\mathrm{Sm}$ & Oft & ${ }^{\text {Alw }}$ \\
\hline 2. & You have finished all your school assignments & $\mathrm{Nv}$ & $\mathrm{Rr}$ & $\mathrm{Sm}$ & Oft & Alw \\
\hline
\end{tabular}

G. The frequency of being grateful due to the following items.

\begin{tabular}{|l|l|l|l|l|l|l|}
\hline 1. & You have kind friend in the school & $\mathrm{Nv}$ & $\mathrm{Rr}$ & $\mathrm{Sm}$ & $\mathrm{Oft}$ & Alw \\
\hline 2. & You are taught by the caring teachers & $\mathrm{Nv}$ & $\mathrm{Rr}$ & $\mathrm{Sm}$ & $\mathrm{Oft}$ & Alw \\
\hline
\end{tabular}

H. The frequency of admiring due to the following items.

\begin{tabular}{|l|l|l|l|l|l|l|}
\hline 1. & Teachers' explanation in the classroom & $\mathrm{Nv}$ & $\mathrm{Rr}$ & $\mathrm{Sm}$ & Oft & Alw \\
\hline 2. & $\begin{array}{l}\text { The effective learning strategies from the classmate for achieving } \\
\text { high academic outcomes }\end{array}$ & $\mathrm{Nv}$ & $\mathrm{Rr}$ & $\mathrm{Sm}$ & Oft & Alw \\
\hline
\end{tabular}

Figure 1. The positive affect scale statements

After preparing the guidelines, the language feasibility was tested to ensure that the sentence in the scale was understandable by the reader and present the same meaning as the researchers' intention (Azwar, 2016). The respondents of the test were seven junior high school students from various levels (two students from the seventh grade, three from the eighth grade, and two from the ninth grade). They also came from various types of schools: 
state, private and Islamic-based schools. Each respondent was asked to examine and provide an assessment on the extent to which the items presented on the scale to be understood.

After making sure with language feasibility, the content validation was following. It was the expert judgment from those who have the relevant scientific capacity to the issue measured, aimed at knowing whether the items were in line with the measured aspects. The assessment was focused on the appropriateness between the item indicators and the measured variables, and the writing procedures, and evaluation for high social desirability (Azwar, 2016). This expert judgment was then calculated using Aiken's $V$ formula to obtain content validity coefficient based on the measured construct (Azwar, 2016).

The obtained scores from the Aiken's $\mathrm{V}$ formula calculation ranged from 0 to 1 , the bigger number of coefficients indicates that the item shows better content validity (Azwar, 2016). The items in the instrument were assessed by 21 experts with educational background at least Master Degree in Psychology. The suitability level between the item and indicator ranged from 1 to 5 (five points): 1 is 'very inappropriate', 2 is 'inappropriate', 3 is 'moderate', 4 is 'appropriate', and 5 is 'very appropriate'. Based on the coefficient Table of Aiken by taking the value $\mathrm{p}=0.01$ ( $1 \%$ margin of error) from 21 assessors, the score limit to be used so the items can be received was 0.71 . The content validation with Aiken coefficient value moved from $0.88-0.96$, the mean value of Aiken (V) was 0.91. Thus, the items are suitable with its indicators according to experts which means the positive affect scale is considered to have good content validity.
The next step after the expert judgment was the item discrimination test. This test was done to obtain items with high discrimination index to distinguish individuals or groups of individuals who have and do not have measured attributes. The approach employed total item consistency which showed the suitability between item functions and its scale functions (Azwar, 2016). The score for each item was correlated with the total score. The high correlation values indicated that the item had a high function towards the overall scale function. The items less than 0.30, according to Azwar (2016), can be interpreted to have a low discrimination index (invalid) so it can be deleted. Based on the item discrimination test using Pearson's total item correlation with the assistance of SPSS V.21, the discrimination index of high positive affect scale items moved from 0.330-0.652. Further, these items were selected to be tested in its construct validity through confirmatory factor analysis.

The item selection on positive affect scale was done by selecting two items having the highest discrimination index on each indicator and considering the item representation as the indicator. The selected items in positive affect scale for confirmatory tests can be seen in Table 2. After obtaining the selected item, the construct validity was done by CFA to test the validity of the scale's indicators as the measurement of latent construct. The construct validity provides the belief that the indicators taken from the sample really illustrate the actual scores in the population. Thus, this analysis confirms empirically based on the sample data to provide theoretical truths for latent variables.

Table 2. The selected items in the Positive Affect Scale for confirmatory tests

\begin{tabular}{cllcc}
\hline Aspect & Indicator & Sub Indicator & Old Version Number & Revised Version Number \\
\hline Task & Process & Joy & $\mathrm{A} 2, \mathrm{~A} 3$ & $\mathrm{~A} 1, \mathrm{~A} 2$ \\
& Prospective & Anticipa-tory joy & $\mathrm{A} 4, \mathrm{~A} 5$ & $\mathrm{~A} 3, \mathrm{~A} 4$ \\
& & Hope & $\mathrm{B} 1, \mathrm{~B} 2$ & $\mathrm{~B} 1, \mathrm{~B} 2$ \\
& \multirow{2}{*}{ Retrospective } & $\mathrm{C} 1, \mathrm{C} 2$ & $\mathrm{C} 1, \mathrm{C} 2$ \\
& & Joy about success & $\mathrm{D} 1, \mathrm{D} 2$ & $\mathrm{D} 1, \mathrm{D} 2$ \\
& & Satisfaction & $\mathrm{E} 1, \mathrm{E} 2$ & $\mathrm{E} 1, \mathrm{E} 2$ \\
& & Pride & $\mathrm{F} 1, \mathrm{~F} 3$ & $\mathrm{~F} 1, \mathrm{~F} 2$ \\
Social & $\mathrm{G} 2, \mathrm{G} 3$ & $\mathrm{G} 1, \mathrm{G} 2$ \\
& & Relief & $\mathrm{A} 7, \mathrm{~A} 8$ & $\mathrm{~A} 7, \mathrm{~A} 8$ \\
& Gratitude & & $\mathrm{H} 1, \mathrm{H} 3$ & $\mathrm{H} 1, \mathrm{H} 2$ \\
& Empathy & & $\mathrm{A} 11, \mathrm{~A} 12$ & $\mathrm{~A} 5, \mathrm{~A} 6$ \\
\hline
\end{tabular}

124 - Copyright (C) 2019, REiD (Research and Evaluation in Education), 5(2), 2019 
Table 3. The Criteria of Goodness-of-Fit (GoF)

\begin{tabular}{lcl}
\hline \multicolumn{1}{c}{ Parameter } & \multicolumn{1}{c}{ Critical Scores } & \multicolumn{1}{c}{ Experts } \\
\hline Chi-Square & Closer to 0 is better & Arbuckle (2013), Kline (2011) \\
Chi-Square/df & $<2$ & Byrne (2001) \\
Probability & $\geq 0.05$ & Kline (2011) \\
GFI & $\geq 0.90$ & Kline (2011), Dachlan (2014), Ghozali (2017) \\
AGFI & $\geq 0.90$ & Kline (2011), Dachlan (2014), Ghozali (2017), \\
CFI & $\geq 0.90$ & Kline (2011), Dachan (2014), Ghozali (2017) \\
TLI & $\geq 0.90$ & Arbuckle (2012), Dachlan (2014), Ghozali (2017) \\
RMSEA & $\leq 0.05$ & Dachlan (2014) \\
\hline
\end{tabular}

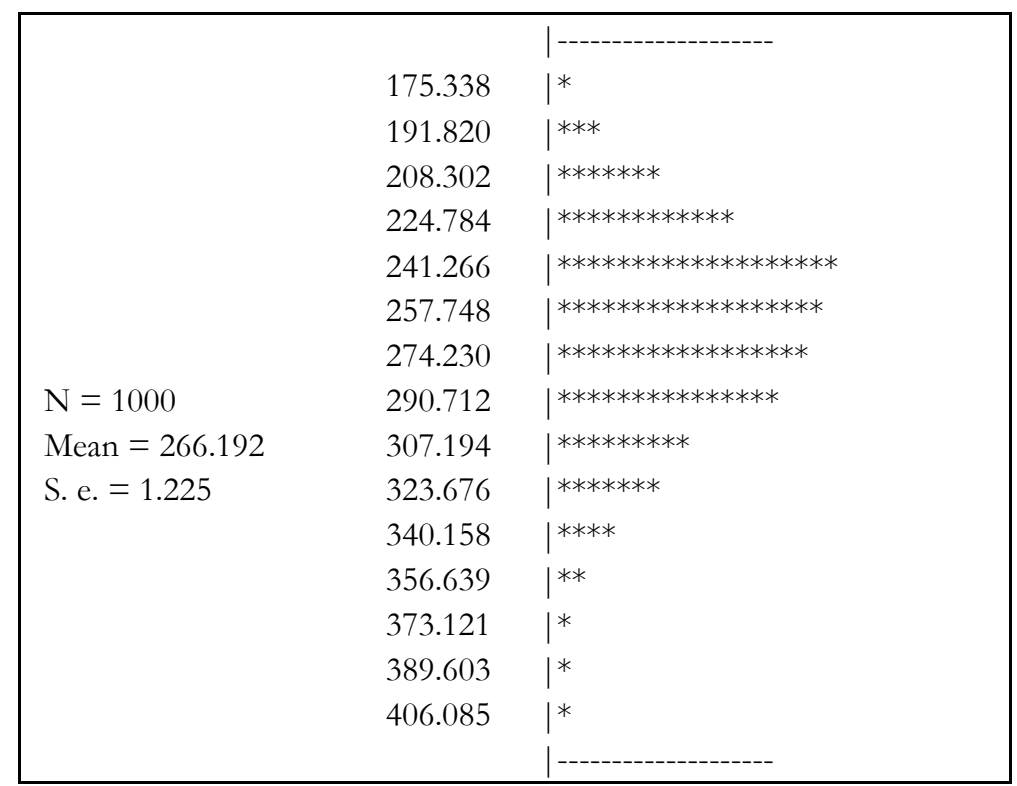

Figure 2. The results of bootstrapping data in Positive Affect Scale

The construct validity can be analyzed from the factor load value (squared multiple correlation) indicators of latent constructs (Ghozali, 2017). To measure the suitability of the model, it was used the measurement of GoF known as the values of CMIN, df, p, GoF, AGFI, TLI, and RMSEA. This GoF standard referred to the opinions of Kline (2011), Arbuckle (2013), and Ghozali (2017). The criteria of GoF can be seen in Table 3.

The factor load value towards the latent construct to maintain the item on positive affect scale was 0.40. It was based on the opinion of Hair, Black, Babin, Anderson, and Tatham (2010) who mention that the determination of the minimum limit of factor load with 200 subjects or more is 0.40 . In line with this ides, Hair et al. (2010) and Netemeyer, Bearden, and Sharma (2003) state that the item should have the factor load of $0.40-0.90$, while the value less than 0.40 should be disregarded.
The confirmatory analysis of positive affect scale used maximum likelihood (ML) estimation method. The requirement that must be fulfilled by ML method was multivariate normality (Byrne, 2010). The multivariate normality test in Positive Affect Scale showed c.r of 35,069 . Because the value of c.r was beyond the range of -2.58 to +2.58 , the data were declared abnormal, so it did not meet the assumption of multivariate normality. To overcome the non-normal data, the bootstrap procedure was applied. The visualization of the bootstrapping results on Positive Affect Scale data with the sample of 1000, the percentile confidence level of $95 \%$, and the bias corrected confidence interval of $95 \%$ can be seen in Figure 2.

Figure 2 showed that Chi-square distribution value with 1000 bootstrap samples in Positive Affect Scale was 266.192; the cluster values in the multivariate center were normal with 266 because there were several values 
above and under 266 that were comparable. After fulfilling the normality requirements of the data, the confirmatory analysis was conducted. The preliminary results indicated that Positive Affect Scale measurement model was not in accordance with the model criteria $(\mathrm{GoF})$, as presented in Figure 3.

In Figure 3, it can be seen that Positive Affect Scale did not meet the measurement model of GoF criteria. This was indicated by Chi-square results $=1286.932$ (relatively high), chi-square $/ \mathrm{df}=209, \mathrm{p}=0.00$ (critical score $\mathrm{p} \geq$ 0.05), GoF, AGFI, TLI, and CFI which was still far below 0.9 (critical value $\geq 0.9$ ) and RMSEA $=0.119$ (critical value $\leq 0.05$ )

To achieve GoF criteria to positive affect scale, the items that can be used were those with loading factor of 0.5 . Thus, the D2 items were deleted since they did not meet the criteria (loading factor $=0.49$ ). The next item selection was by paying attention to the modi- fication suggestions by AMOS program, such as removing items Affect C2, F2, E1, A6, G2, E1, A4, E2, A8, H2, A5, D1, B2, and G1 since it had variance with some other items (cross-loading) with relatively high MI values.

Based on the modifications made, positive affect scale can reach the measurement fit value as shown in Figure 4, i.e. Chi-square of 15.602 with $\mathrm{p}=0.76$; Chi-square $/ \mathrm{df}=1.734$; $\mathrm{GFI}=0.986$; $\mathrm{AGFI}=0.967$; $\mathrm{TLI}=0.978$; $\mathrm{CFI}=$ 0.987; and RMSEA $=0.045$ according to the established GoF criteria. In detail, a summary of the analysis of Positive Affect Scale factors based on GoF criteria can be seen in Table 4 .

Six items are selected in Table 4: affect A1, A3, B1 (related to the assignment aspects) and affect $\mathrm{A} 7$ and $\mathrm{H} 1$ (representing the social aspects). After modifications, items in the positive affect scale had been empirically confirmed to the established GoF criteria.

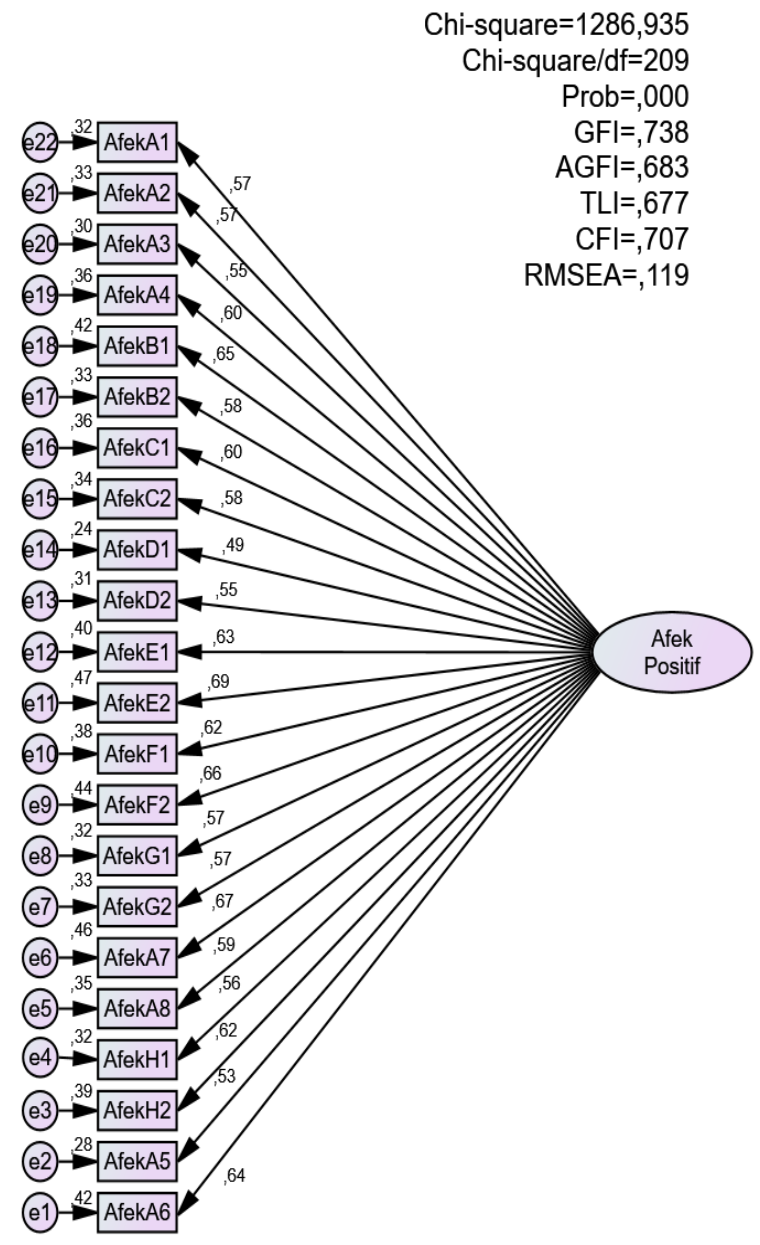

Figure 3. Analysis of confirmatory factors on Positive Affectivity Scale which is not accordance with the criteria of Goodness of Fit (GoF) 


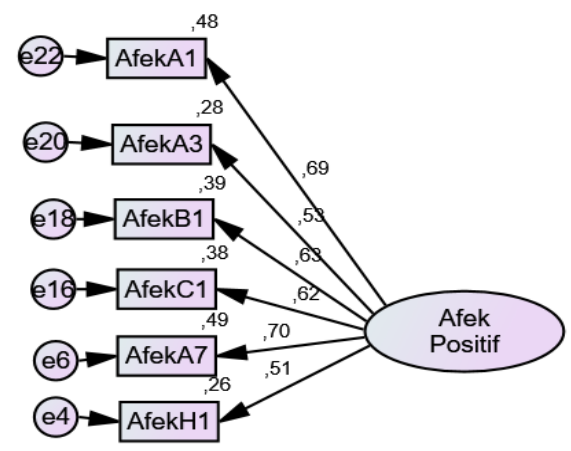

Figure 4. CFA on Positive Affect Scale based on Goodness of Fit (GoF)

Table 4. Summary of CFA on Positive Affect Scale based on GoF

\begin{tabular}{cccc}
\hline Aspect & Item & Scores of Loading Factors & Significance (p) \\
\hline Assignment & AffectA1 & 0.691 & significant \\
& AffectA3 & 0.531 & significant \\
& AffectB1 & 0.628 & significant \\
& AffectC1 & 0.616 & significant \\
Social & AffectA7 & 0.699 & significant \\
& AffectH1 & 0.506 & significant \\
\hline
\end{tabular}

Discussion

This research is one of several stages before testing the structural model of positive affect scale as one of the research instruments. The results of the study indicate that the positive affect scale in the academic setting is able to produce items that can reveal the latent constructs or concepts appropriately. There are six selected items in which four items represent the assignment aspects, and two items are related to the social aspects.

Associated with the development of positive affect instruments by Watson et al. (1988), positive affect instruments in the academic domain generated through this research enriched the study of previous positive affect instruments. The positive affect instrument of Watson et al., (1988) was general for all domains, while the positive affect instrument resulting from this study is more specifically revealing the positive affect that develops in academic settings. Thus, the discussion on positive effects in academic settings becomes more detailed and clear according to context.
This study can give beneficial contribution dealing with the limited studies on the affect in the academic setting as stated by Linnenbrink-Garcia and Pekrun (2011) and Pekrun et al. (2002). It is expected that psychological dynamics within the academic context can be investigated comprehensively to build appropriate and efficient solution towards various educational problems.

\section{Conclusion}

It is concluded that the validity test of positive affect scale within the academic domain can produce items that can reveal constructs or latent concepts appropriately. By having correct and proper information related to psychological dynamics within the academic context, it can support to create appropriate and efficient solution for various educational problems to improve the quality of education. Further studies are expected to continue its coverage on a wider range of area to see if the research findings can be applied to other unexamined subjects and contexts. 


\section{References}

Aiken, L. R. (1985). Three coefficients for analyzing the reliability and validity of ratings. Educational and Psychological Measurement, 45(1), 131-142. https:// doi.org/10.1177/0013164485451012

Arbuckle, J. L. (2013). IBM® SPSS® AmosTM 22 user's guide. Chicago, IL: Amos Development Corporation.

Ashby, F. G., Isen, A. M., \& Turken, A. U. (1999). A neuropsychological theory of positive affect and its influence on cognition. Psychological Review, 106(3), 529-550. https://doi.org/10.1037/003 3-295X.106.3.529

Azwar, S. (2016). Konstruksi tes kemampuan kognitif. Yogyakarta: Pustaka Pelajar.

Byrne, B. M. (2010). Structural Equation Modeling with AMOS: Basic concept, application, and programming (2nd ed.). New York, NY: Routledge Taylor \& Francis Group.

Dachlan, U. (2014). Panduan lengkap Struktural Equation Modeling tingkat dasar: Metodologi, konsepsi, aplikeasi (dengan Amos) (1st ed.). Semarang: Lentera Ilmu.

Danner, D. D., Snowdon, D. A., \& Friesen, W. V. (2001). Positive emotions in early life and longevity: Findings from the nun study. Journal of Personality and Social Psychology, 80(5), 804-813. https:// doi.org/10.1037/0022-3514.80.5.804

Demanet, J., Liefooghe, B., \& Verbruggen, F. (2011). Valence, arousal, and cognitive control: A voluntary task-switching study. Frontiers in Psychology, 2(336), 1-9. https://doi.org/10.3389/fpsyg.2011.00 336

Folkman, S. (2008). The case for positive emotions in the stress process. Anxiety, Stress and Coping, 21(1), 3-14. https:// doi.org/10.1080/10615800701740457

Fredrickson, B. L. (1998). What good are positive emotions? Review of General Psychology, 2(3), 300-319. https://doi. org/10.1037/1089-2680.2.3.300
Fredrickson, B. L., \& Joiner, T. (2002). Positive emotions trigger upward spirals toward emotional well-being. Psychological Science, 13(2), 172-175. https:// doi.org/10.1111/1467-9280. 00431

Fredrickson, B. L., Mancuso, R. A., Branigan, C., \& Tugade, M. M. (2000). The undoing effect of positive emotions. Motivation and Emotion, 24(4), 237-258. https://doi.org/10.1023/a:1010796329 158

Fredrickson, B. L., Tugade, M. M., Waugh, C. E., \& Larkin, G. R. (2003). What good are positive emotions in crisis? A prospective study of resilience and emotions following the terrorist attacks on the United States on September 11th, 2001. Journal of Personality and Social Psychology, 84(2), 365-376. https://doi. org/10.1037/0022-3514.84.2.365

Ghozali, I. (2017). Model persamaan struktural Kkonsep dan aplikasi dengan program AMOS 24 Update Bayesian SEM (7th ed.). Semarang: Badan Penerbit Universitas Diponegoro.

Goetz, T., Pekrun, R., Hall, N., \& Haag, L. (2006). Academic emotions from a social-cognitive perspective: Antecedents and domain specificity of students' affect in the context of Latin instruction. British Journal of Educational Psychology, 76(2), 289-308. https:// doi.org/10.1348/000709905X42860

Hair, G., Black, B., Babin, B., Anderson, R., \& Tatham, R. (2010). Multivariate data analysis (7th ed.). Upper Saddle River, NJ: Pearson.

Kline, R. (2011). Principle and practice of Sructural Equation Modeling (3rd ed.). New York, NY: The Guilford Press.

Linnenbrink-Garcia, L., \& Pekrun, R. (2011). Students' emotions and academic engagement: Introduction to the special issue. Contemporary Educational Psychology, 36(1), 1-3. https://doi.org/10.1016/ j.cedpsych.2010.11.004

Linnenbrink, E. A. (2006). Emotion research in education: Theoretical and 
Psychometric characteristic of positive affect scale within... Kartika Nur Fathiyah, Asmadi Alsa, \& Diana Setiyawati

methodological perspectives on the integration of affect, motivation, and cognition. Educational Psychology Review, 18(4), 307-314. https://doi.org/10.10 07/s10648-006-9028-x

Lyubomirsky, S., King, L., \& Diener, E. (2005). The benefits of frequent positive affect: Does happiness lead to success? Psychological Bulletin, 131(6), 803-855. https://doi.org/10.1037/003 3-2909.131.6.803

Nath, P., \& Pradhan, R. K. (2012). Influence of positive affect on physical health and psychological well-being: Examining the mediating role of psychological resilience. Journal of Health Management, 14(2), 161-174. https://doi.org/10. 1177/097206341201400206

Netemeyer, R. G., Bearden, W. O., \& Sharma, S. (2003). Scaling procedures: Issues and applications. https://doi.org/10.4135/97 81412985772

Pekrun, R. (1992). The impact of emotions on learning and achievement: Towards a theory of cognitive/motivational mediators. Applied Psychology, 41(4), 359376. https://doi.org/10.1111/j.146405 97.1992.tb00712.x

Pekrun, R., Goetz, T., Titz, W., \& Perry, R. P. (2002). Academic emotions in students' self-regulated learning and achievement: A program of qualitative and quantitative research. Educational Psychologist, 37(2), 91-105. https://doi. org/10.1207/S15326985EP3702_4

Pekrun, R., Goetz, T., Titz, W., Perry, R. P., Pekrun, R., Goetz, T., ... Perry, R. P. (2010). Academic Emotions in Students ' Self-Regulated Learning and Acbievement: A Program of Qualitative and Quantitative Research Academic Emotions in Students' Self-Regulated Learning and Achievement: A Program of Qualitative and Quantitative
Research. (October 2014), 37-41. https:/ /doi.org/10.1207/S15326985EP3702

Samios, C., Abel, L. M., \& Rodzik, A. K. (2013). The protective role of compassion satisfaction for therapists who work with sexual violence survivors: An application of the broaden-and-build theory of positive emotions. Anxiety, Stress \& Coping, 26(6), 610-623. https://doi.org/ 10.1080/10615806.2013.784278

Schutz, P. A., \& Lanehart, S. L. (2002). Introduction: Emotions in education. Educational Psychologist, 37(2), 67-68. https://doi.org/10.1207/S15326985EP 3702_1

Seligman, M. E. P., Ernst, R. M., Gillham, J., Reivich, K., \& Linkins, M. (2009). Positive education: Positive psychology and classroom interventions. Oxford Review of Education, 35(3), 293-311. https://doi.org/10.1080/03054980902 934563

Steptoe, A., Dockray, S., \& Wardle, J. (2009). Positive affect and psychobiological processes relevant to health. Journal of Personality, 77(6), 1747-1776. https:// doi.org/10.1111/j.1467-6494.2009.005 99.x

Watson, D., Clark, L. A., \& Tellegen, A. (1988). Development and validation of brief measures of positive and negative affect: The PANAS scales. Journal of Personality and Social Psychology, 54(6), 1063-1070. https://doi.org/10.1037/ 0022-3514.54.6.1063

Watson, D., \& Tellegen, A. (1985). Toward a consensual structure of mood. Psychological Bulletin, 98(2), 219-235. https:// doi.org/10.1037/0033-2909.98. 2.219

Yik, M., Russell, J. A., \& Steiger, J. H. (2011). A 12-point circumplex structure of core affect. Emotion, 11(4), 705-731. https:// doi.org/10.1037/a0023980 